\title{
LETTER
}

\section{Sarcoid granulomatosis after zirconium exposure with multiple organ involvement}

\author{
U. Werfel*, J. Schneider*, K. Rödelsperger+, J. Kotter*, W. Popp*, H.J. Woitowitz*, G. Zieger
}

\section{To the Editor:}

A 51 yr old, nonsmoking female suffered from relapsing progressive pneumonia for several years. The patient had worked for $16 \mathrm{yrs}$ in the nuclear industry and was exposed to grinding particles and welding fumes working with zirkaloy, an alloy containing tin, iron, chromium and zirconium. During an exacerbation of the pneumonia radiography of the lung showed interstitial infiltrations of both lower lobes. Extended diagnostic procedures could not confirm an infectious disease. In addition, nodular and painful thickenings appeared in old operation scars on the left breast and right hand, and near former injection points on the buttocks and abdominal wall. The scar tissue of the left breast and an axiliary lymph node were examined histologically after excision. Both tissues showed many epithelioid cell granulomas with giant cells, while foreign bodies were only seen in the skin. Persistent infiltrations of the lung led to lobectomy of the right lower lobe and partial resection of the middle lobe in order to exclude a malignant disease. The histological picture of the lung tissue showed different stages of alterations with pronounced proliferation of the alveolar epithelium, epithelioid cell granulomas between well-presented alveolar walls and additional large areas of scarred tissue [1]. Regression of the pulmonary infiltrations was observed within a few weeks of beginning corticosteroid therapy with $24 \mathrm{mg}$ prednisone daily. The initial pulmonary function test showed a normal vital capacity and a reduced timed vital capacity (Tiffeneau test), which was normal in a control examination 6 months later.

Zirconium is a noncorrosive material which is used as pure metal or alloy in, for example, the aircraft, aerospace and nuclear industries [2]. It is known from both human experience [3] and animal studies [4] that zirconium can cause hypersensitivity reactions of the skin with epithelioid cell granulomas after repeated topical application of deodorants containing soluble and insoluble zirconium salts. Pulmonary alterations such as radiographic shadows, granulomas and interstitial fibrosis were observed in animal studies after zirconium exposure [5-7]. In humans pulmonary alterations are reported only rarely [8-12]. There are only a few case reports of zirconium-related lung diseases, in particular pulmonary granulomatous alterations $[11,12]$.

In order to confirm zirconium as the causative agent of the disease, lung tissue was examined by scanning transmission electron microscopy. Intracellular particles in lung granulomas could be identified as zirconium, along with iron, chromium and silicon [13]. Beryllium, a possible occupational agent which is able to induce granulomas, could not be found.

Nearly 10 yrs after the diagnosis $[1,13]$ the patient was free of complaints under ongoing therapy with $6 \mathrm{mg}$ pred-

*Institute of Hygiene and Occupational Medicine, University of Essen, Germany. +Institute of Occupational and Social Medicine, University of Giessen, Germany. Institute of Pathology, Community Hospital, Hanau, Germany. nisone daily and suffered from a mild obstructive lung disease. The granulomatous disease was regarded as valid for compensation by the German occupational accident insurances.

Most cohort studies in workers exposed to zirconium do not show pulmonary alterations $[14,15]$. This may suggest that a special susceptibility is responsible for the development of a granulomatous disease after zirconium exposure. In any case, zirconium must be considered as another metal, besides beryllium, which can cause pulmonary and generalized granulomatosis.

\section{References}

1. Kotter JM, Zieger G. Sarkoidale Granulomatose nach mehrjähriger Zirkoniumexposition, eine "Zirkoniumlunge". Pathologe 1992; 13: 104-109.

2. Stokinger HE. The metals. In: Clayton GD, Clayton FE, eds. Patty's Industrial Hygiene and Toxicology, 3rd rev. edn. New York, John Wiley \& Sons, 1981; pp. 2049-2060.

3. Epstein WL. Granulomatous hypersensitivity. Prog Allergy 1967; 11: 36-88.

4. Turk JL, Parker D. Granuloma formation in normal guinea pigs injected intradermally with aluminium and zirconium compounds. J Invest Dermatol 1977; 68: 336-340.

5. Harding HE, Davis TAL. The experimental production of radiographic shadows by inhalation of industrial dusts. Part II: Zirconium. Br J Ind Med 1952; 9: 70-73.

6. Prior JT, Cronk GA, Ziegler DD. Pathological changes with the inhalation of sodium zirconium lactate. Arch Environ Health 1960; 1: 297-300.

7. Brown JR, Mastromatteo E, Horwood J. Zirconium lactate and barium zirconate: acute toxicity and inhalation effects in experimental animals. Am Ind Hyg Assoc J 1963; 24: 131-136.

8. Reed CE. A study of the effects on the lungs of industrial exposure to zirconium dusts. Arch Ind Health 1956; 13: 578-580.

9. Bartter T, Irwin RS. Zirconium compound-induced pulmonary fibrosis. Arch Inter Med 1991; 151: 1197-1201.

10. McCallum RC. The work of an occupational hygiene service in environmental control. Ann Occup Hyg 1963; 6: 55-63.

11. Liippo KK, Anttila SL, Taikina-Aho O, Ruokonen E-L, Toivonen ST, Tuomi T. Hypersensitivity pneumonitis and exposure to zirconium silicate in a young ceramic tile worker. Am Rev Respir Dis 1993; 148: 1089-1092.

12. Romeo L, Cazzadori A, Bontempini L, Martini S. Interstitial lung granulomas as a ssible consequence of exposure to zirconium dust. Med Lav 1994; 85: 219-222.

13. Schneider J, Freitag F, Rödelsperger K. Durch Zirkonium-Einwirkung am arbeitsplatz verursachte exogen-allergische Alveolitis (No. 4201 BeKV). Arbeitmed Sozialmed Umweltmed 1994; 9: 382-385.

14. Marcus RL, Turner S, Cherry NM. A study of lung function and chest radiographs in men exposed to zirconium compounds. Occup Med 1996; 46: 109-113.

15. Hadjimichael OC, Brubaker RE. Evaluation of an occupational respiratory exposure to a zirconium-containing dust. J Occup Med 1981; 23: 543-547. 